JIAT 1 (1) 49-63 (2018)

\title{
Pengaruh Kinerja Lingkungan dan Kinerja Komite Audit Terhadap Kinerja Ekonomi Perusahaan
}

\author{
Prasetyo $^{1}$, Suwarno ${ }^{2 *}$, Suwandi $^{3}$ \\ 1,2,3 Universitas Muhammadiyah Gresik
}

\begin{abstract}
This study aims to examine the influence of environmental performance and audit committee performance on the economic performance of the company. This type of research is quantitative research. The sample used in this study were 66 manufacturing companies listed on the Indonesia Stock Exchange. The sampling technique uses purposive sampling, with the criteria of manufacturing companies that publish annual reports on the Indonesia Stock Exchange and follow the PROPER assessment. Data analysis in this study using multiple linear regression. The results of the study showed that the variable environmental performance and audit committee performance had a significant effect on the economic performance of the company.
\end{abstract}

Keywords: environmental performance, audit committee performance, economic performance of companies, proper.

Tipe artikel: Empiris

\section{Pendahuluan}

\subsection{Latar Belakang Masalah}

Menurut Almilia dan Wijiyanto (2007), kinerja perusahaan yang secara relatif berubah-berubah dari tahun ke tahun dalam suatu kelompok industri yang bergerak dalam usaha yang sama (industri sejenis) yang ditandai dengan besarnya return tahunan perusahaan disebut dengan kinerja ekonomi perusahaan. Yang mana, kinerja ekonomi yang baik dapat menggambarkan peningkatan keberhasilan produktivitas suatu perusahaan yang baik pula. Hal tersebut dapat dengan jelas diungkapkan dalam laporan keuangan tahunan perusahaan. Perusahaan yang memiliki kinerja ekonomi baik dapat menunjang sebuah perusahaan untuk meraih tujuan jelas didirikannya perusahaan yaitu untuk memperoleh keuntungan dan untuk menarik investor agar berinvestasi pada perusahaan tersebut.

Namun, dengan meningkatkanya produktivitas perusahaan, banyak perusahaan yang lalai akan permasalahan lingkungan yang disebabkan oleh aktivitas produksinya. Dewasa ini, fenomena permasalahan lingkungan di Indonesia terjadi disebabkan dari dampak buruknya pengelolaan lingkungan yang memprihatinkan. Hal tersebut dapat dilihat dari berbagai bencana yang terjadi akhirakhir ini, seperti banjir dan tanah longsor yang terjadi hampir di seluruh daerah di Indonesia. Peristiwa

\footnotetext{
${ }^{*}$ Penulis yang sesuai:

E-mail: suwarno@umg.ac.id

Afiliasi: Universitas Muhammadiyah Gresik
} 
ini menunjukkan sebagai bukti rendahnya perhatian perusahaan terhadap dampak lingkungan yang ditimbulkan akibat dari aktivitas industrinya.

Oleh karena itu, masyarakat menuntut kepada perusahaan untuk memperhatikan secara khusus dampak lingkungan yang timbul dari kegiatan produksi perusahaan. Hasilnya, perusahaan menanggapi dengan baik tuntutan tersebut yaitu dengan mengadakan kegiatan-kegiatan peduli lingkungan yang terprogram. Kegiatan atas peduli lingkungan tersebut dicatat secara khusus sebagai anggaran yang secara tidak langsung akan mendatangkan benefit bagi perusahaan itu sendiri. Konsep tersebut sering disebut sebagai akuntabilitas lingkungan. Akan tetapi, penerapan akuntabilitas lingkungan di negara berkembang masih sangat kurang termasuk salah satunya di Indonesia. Hal itu dikarenakan lemahnya sanksi hukum yang berlaku di Indonesia terhadap permasalahan lingkungan yang ditimbulkan oleh sebuah perusahaan.

Salah satu upaya pemerintah melalui Kementrian Lingkungan Hidup (KLH) untuk mendorong peningkatan peran perusahaan dalam pengelolaan kelestarian lingkungan hidup yaitu melalui dibentuknya Program Penilaian Peringkat Kinerja Perusahaan dalam Pengelolaan Lingkungan Hidup (PROPER) yang telah dimulai sejak tahun 2002. PROPER Kementerian Negara Lingkungan Hidup (2017) ini membantu penaatan perusahaan dalam pengelolaan lingkungan hidup melalui instrumen informasi yang dilakukan melalui berbagai pengarahan kegiatan yang bertujuan untuk: (i) mendorong perusahaan agar menaati peraturan perundang-undangan melalui insentif dan disinsentif reputasi, dan (ii) mendorong perusahaan yang sudah baik kinerja lingkungannya untuk menerapkan produksi bersih (cleaner production).

Akuntabilitas sebagai aspek dari Good Corporate Governance (GCG) sangat lah penting ketika manajemen menghadapi pilihan antar waktu (intertemporal choice). Hal ini berkenaan dengan bagaimana keadaan itu memaksa manajemen perusahaan melakukan manipulasi karena situasi yang dihadapinya, untuk dapat mengelola pengeluaran-pengeluaran yang akan memberikan manfaat di masa depan. Dengan tujuan menyesatkan pemegang saham yang ingin mengetahui kinerja ekonomi perusahaan dengan mengubah laporan keuangan, atau untuk mempengaruhi hasil kontraktual yang mengandalkan angka akuntansi yang dilaporkannya, adalah beberapa contoh bagaimana melakukan manipulasi tersebut berdasarkan Watts dan Zimmerman (1986). Sehingga dengan sebab itu, manajemen atau perusahaan perlu membentuk komite audit untuk menghindari manipulasi seperti tersebut di atas.

Penerapan prinsip ini berkaitan dengan integritas laporan keuangan, yaitu antara lain nantinya dapat terlihat dari ketiadaan permasalahan penyajian laporan keuangan. Dapat dikatakan bahwa permasalahan dalam pelaporan keuangan perusahaan publik dapat dilihat dari adanya sanksi dari Badan Pengawas Pasar Modal (BAPEPAM). Selain itu, di sisi lain, beberapa penelitian juga menunjukkan hubungan positif antara kehandalan laporan keuangan dengan kualitas Good Corporate Governance. Karena berdasarkan pendapat dari Dechow et al (1996), kecurangan laporan keuangan lebih mungkin didapati pada perusahaan tanpa komite. Dan juga dijelaskan oleh Anderson et al (2003) bahwa komite audit yang berkualitas mampu melakukan manajemen laba dalam perusahaan sehingga pendapatan perusahaan bisa meningkat.

Di samping itu, Siallagan dan Machfoedz (2006) juga menyatakan bahwa investor, analis dan regulator menganggap komite audit memberikan kontribusi dalam kualitas pelaporan keuangan. Oleh sebab itu, dapat dikatakan bahwa komite audit mampu meningkatkan integritas dan kredibilitas pelaporan keuangan melalui beberapa hal ini: (1) pengawasan atas proses pelaporan termasuk sistem pengendalian internal dan penggunaan prinsip akuntansi berterima umum, dan (2) mengawasi proses audit secara keseluruhan. Hasil dari hal tersebut mengindikasikan bahwa adanya komite audit memiliki konsekuensi pada laporan keuangan, yaitu pada: (1) berkurangnya pengukuran akuntansi yang tidak tepat, (2) berkurangnya pengungkapan akuntansi yang tidak tepat, dan (3) berkurangnya tindakan kecurangan manajemen dan tindakan ilegal.

Untuk mengetahui kinerja ekonomi perusahaan dengan tepat, banyak sekali teknik pengukuran kinerja yang telah dibuat dan dipakai oleh kalangan pemilik modal maupun para manajer perusahaan. Salah satu cara untuk mengetahui kinerja perusahaan adalah dengan melakukan analisis terhadap kondisi keuangan perusahaan yang tercermin dalam return harga saham perusahaan. Melalui fluktuasi harga saham perusahaan, pencapaian kinerja ekonomi perusahaan dapat dilihat dari respon positif investor. Sehingga, merupakan good news bagi investor dan calon investor apabila perusahaan itu memiliki track record dengan kinerja lingkungan yang baik. Hal tersebut telah dibuktikan oleh Suratno, dkk (2006) yang menemukan pengaruh signifikan antara kinerja lingkungan dan kinerja ekonomi dalam suatu perusahaan.

Investor atau calan investor menggunakan laporan tahunan sebagai pedoman dalam melihat prospek perusahaan. Pengungkapan informasi yang terdapat dalam laporan tahunan perusahaan dapat 
memberikan analisa laporan keuangan untuk menilai kinerja perusahaan. Sebagian besar pengungkapan dalam laporan keuangan tahunan memuat informasi sosial mengenai tenaga kerja, lingkungan dan masyarakat. Alasan pengungkapan yang dilakukan perusahaan terhadap informasi sosial merupakan subjek yang banyak diambil dalam penelitian yang telah dilakukan oleh Epsten \& Freedman (1994) dan dalam penelitian milik Lindrianasari (2007). Selain itu, dapat diketahui bahwa menurut Daeegan \& Rankin (1997) dalam penjelasan yang dipaparkan dalam laporan hasil penelitian Lindianasari (2007), menerangkan bahwasanya kebanyakan dalam penelitian tersebut menyatakan bahwa responden akan melakukan tindakan yang berbeda terhadap keputusan investasi pada kondisi mereka memperoleh informasi sosial dan pada kondisi tidak memperoleh informasi sosial.

Dijelaskan oleh Gray (1993) dalam Lindrianasari (2007), yaitu bahwa pengungkapan lingkungan merupakan bagian dari pengungkapan laporan keuangan. Banyak studi yang menguji lebih lanjut tentang informasi sosial yang dihasilkan oleh perusahaan dan ditemukan bahwa informasi lingkungan merupakan salah satu bagian dari informasi tersebut. Lebih jauh lagi, Gray menyatakan pengungkapan lingkungan merupakan bagian esensi terpenting dari suatu laporan keuangan.

Pelaporan lingkungan dalam annual report di sebagian besar negara termasuk Indonesia masih bersifat voluntary. Meskipun begitu, kewajiban pelaporan mengenai dampak lingkungan di Indonesia telah ditetapkan oleh Keputusan Menteri Lingkungan Hidup No 17 Tahun 2001 tentang Jenis Rencana Usaha dan/atau Kegiatan yang Wajib Dilengkapi dengan Analisis Mengenai Dampak Lingkungan Hidup. Dan diatur juga di dalam Undang- Undang No. 23 tahun 1997 tentang Pengelolaan Lingkungan Hidup.

Review yang dilakukan oleh Berthelot, et al, pada tahun 2003 menunjukkan bahwa penelitian mengenai hubungan antara pengungkapan lingkungan dengan kinerja keuangan cukup banyak dilakukan. Diterangkan bahwa beberapa peneliti pada umumnya menggunakan variabel kinerja keuangan atau pasar modal sebagai prediktor bagi kinerja lingkungan atau pengungkapan lingkungan itu sendiri. Sedangkan di Indonesia sendiri, penelitian yang menguji hubungan kedua variabel telah dilakukan oleh Sarumpaet pada tahun 2005. Dari hasil investigasi penelitian terdahulu tersebut, nampak bahwa penelitian yang menggunakan variabel non keuangan sebagai prediktor kinerja lingkungan masih dilakukan. Disamping itu, penelitian mengenai faktor-faktor yang mempengaruhi pengungkapan kinerja lingkungan dalam annual report juga masih sangat jarang dilakukan (Berthelot, et al, 2003). Dalam penelitian Siregar, Lindrianasari dan Komaruddin (2013) mengujikan hubungan antara kinerja lingkungan dan kinerja komite audit dengan kualitas pengungkapan CSR menunjukkan signifikansi diantara variabel yang ada.

\subsection{Rumusan Masalah}

Berdasarkan uraian latar belakang di atas, rumusan masalah dari penelitian ini adalah:

1. Apakah kinerja lingkungan berpengaruh terhadap kinerja ekonomi perusahaan?

2. Apakah kinerja komite audit berpengaruh terhadap kinerja ekonomi perusahaan?

\subsection{Kontribusi Penelitian}

Penelitian ini memfokuskan pada pengembangan penelitian terdahulu, yaitu yang berjudul "Hubungan Antara Kinerja Lingkungan dan Kinerja Komite Audit dengan Kualitas Pengungkapan CSR" yang telah dilakukan oleh Lindrianasari Siregar dan Komaruddin pada tahun 2013. Dengan mengganti variabel dependen dengan Kinerja Ekonomi Perusahaan. Penggantian variabel dilakukan karena terdapat kerterbatasan indikator pengungkapan CSR. Kinerja ekonomi perusahaan diukur menggunakan perhitungan skala hitung economic performance Al-Tuwaijri yang merujuk pada penelitiannya di tahun 2004 yang memiliki judul "The Relations Among Environmental Disclosure, Environmental Performance, and Economic Performance: A Simultaneous Equations Approach".

\section{Tinjauan Pustaka}

\subsection{Penelitian Sebelumnya}

Beberapa penelitian telah dilakukan, yang berhubungan dengan kinerja lingkungan, kinerja komite audit dan kinerja keuangan. Ivana, Lindrianasari dan Komaruddin (2013) melakukan penelitian mengenai hubungan antara kinerja lingkungan dan kinerja komite audit dengan kualitas pengungkapan corporate 
social responsibility. Dalam penelitian tersebut dibuktikan kedua variabel (kinerja lingkungan dan kinerja audit) berpengaruh signifikan terhadap pengungkapan CSR.

Lindrianasari (2007) melakukan penelitian utnuk mengetahui sejauh mana kinerja lingkungan memberikan pengaruh terhadap pengungkapan lingkungan dan pengungkapan lingkungan terhadap kinerja ekonomi. Data yang digunakan adalah perusahaan yang terdaftar di BEI (80 perusahaan) dan PROPER tahun 2014. Hasilnya, terdapat pengaruh antra kinerja lingkungan dan pengungkapan lingkungan, akan tetapi tidak ada hubungan antara pengungkapan lingkungan dan kinerja ekonomi.

Al-Tuwaijri, et al. (2004) dalam studinya mencoba memberikan analisis terpadu mengenai bagaimana manajemen secara keseluruhan berpengaruh terhadap pengungkapan lingkungan, kinerja lingkungan dan kinerja ekonomi. Hasil dari penelitian tersebut ditemukan bahwa terdapat hubungan positif yang signifikan antara kinerja ekonomi yang diukur menggunakan perhitungan selisih antara annual stock return dengan kinerja lingkungan.

Siallagan dan Machfoedz (2006) juga melakukan penelitian tentang mekanisme corporate governance, kualitas laba dan nilai perusahaan. Data penelitian yang digunakan adalah perusahaan manufaktur yang terdaftar di BEJ (Bursa Efek Jakarta) yang memiliki data kepemilikan manajerial, dewan komisaris, dan komite audit dan juga menerbitkan laporan keuangan untuk periode yang berakhir 31 Desember selama periode pengamatan 2000-2004. Hasil penelitian menyebutkan bahwa mekanisme corporate governance mempengaruhi kualitas laba sehingga secara positif berpengaruh terhadap nilai perusahaan.

Anderson, et al (2003) meneliti mengenai dewan direksi, komite audit, dan informasi pendapatan pada laporan keuangan. Disebutkan di dalamnya bahwa pendapatan menjadi lebih besar dan informatif dengan komposisi dewan yang lengkap. Karakteristik komite audit juga mempengaruhi informasi pendapatan. Apalagi pada perusahaan yang jabatan CEO dan dewan direksi dipisah, sehingga laporan pendapatan bisa dibilang lebih informatif.

\subsection{Landasan Teori}

\subsubsection{Teori Legitimasi}

Teori legitimasi menjelaskan perusahaan melakukan kegiataan usaha dengan batasan-batasan yang ditentukan oleh norma-norma, nilai-nilai sosial dan reaksi terhadap batasan tersebut mendorong pentingnya perilaku organisasi dengan memperhatikan lingkungan (Ghozali dan Chariri, 2007:411). Legitimasi ada karena adanya kesesuaian antara kegiatan organisasi dan harapan masyarakat. Perusahaan dikatakan memiliki legitimasi ketika sistem nilai perusahaan selarsan dengan sistem nilai kemasyarakat. Legitimasi adalah hal penting bagi perusahaan karena legitimasi masyarakat terhadap perusahaan dijadikan acuan dalam perkembangan sebuah perusahaan. Menurut Gray et al (1996: 46) legitimasi merupakan sistem pengelolaan perusahaan yang berorientasi pada keberpihakan terhadap masyarakat, pemerintah individu dan kelompok masyarakat.

Dalam penilaian PROPER, indikator penilaian tidak hanya difokuskan pada lingkungan hidup saja, namun juga kontribusi terhadap masyarakat. Proper emas diberikan kepada perusahaan yang secara konsisten menunjukkan keunggulan lingkungan lebih dari yang dipersyaratkan dan melakukan upayaupaya pengembangan masyarakat secara berkesinambungan. Masyarakat akan menilai jika kinerja kelangsungan organisasi atau perusahaan sesuai dengan sistem nilai masyarakat, maka akan dipastikan perusahaan atau organisasi akan berlajut keberadaannya.

\subsubsection{Teori Persinyalan (Signaling Theory)}

Teori persilangan memfokuskan pentingnya informasi yang akan dikeluarkan terhadap keputusan investasi pihak luar. Informasi berupa catatan penting perusahaan yang ada di masa lalu, sekarang dan juga proyeksi yang akan datang. Dalam teori persinyalan ditunjukkan adanya asimetris informasi antara manajemen perusahaan dan pihak-pihak yang berkepentingan dengan informasi tersebut, serta pengemukaan tentang bagaimana seharusnya perusahaan memberikan sinyal-sinyal kepada pengguna laporan keuangan. Berdasarkan T.C. Melwar (2008:100) yang menyatakan tentang teori sinyal, hal ini menunjukkan bahwa perusahaan akan memberikan sinyal melalui tindakan dan komunikasi. Perusahaan mengapdosi sinyal-sinyal untuk mengungkapkan atribut yang tersembunyi untuk para pemangku kepentingan. 


\subsubsection{Akuntanbilitas Lingkungan}

Praktik akuntansi adalah sebagai pioner dalam mewujudkan akuntabilitas. Sekarang ini telah dilaporkan tidak lebih dari sekedar akun simpulan dari aktivitas ekonomi entitas pelaporan. Laporan keuangan disusun atas basis ekonomi dan nilai uang. Akun laba atau rugi sebagai laporan kinerja menyediakan gambaran laba atau rugi keuangan yang dihasilkan oleh entitas. Neraca sebagai laporan posisi keuangan menyediakan simpulan posisi keuangan entitas pada akhir periode akuntansi. Kedua laporan tersebut belum mampu merefleksikan aktivitas entitas secara menyeluruh, mungkin memang tidak akan mampu. Namun demikian, akuntansi harus selalu berkembang hingga mampu menangkap dimensi 'gambar' entitas yang lebih menyeluruh, dalam studi ini terfokus pada aspek lingkungan. Sehingga pengambil keputusan, dan seluruh pemangku kepentingan terwadahi semua dan memiliki dasar yang lebih menyeluruh dalam mengambil keputusan.

Akuntabilitas lingkungan, sebagaimana telah dijelaskan di atas, merupakan salah satu cara untuk mengurangi kerusakan lingkungan harus didorong perwujudannya. Perwujudan ini diharapkan terwadahi oleh akuntansi, namun akuntansi konvensional belum mampu memikul harapan tersebut. Akuntansi konvensional dapat berkontribusi baik langsung maupun tidak langsung dalam menciptakan atau menghambat kerusakan lingkungan (Maunders dan Burritt, 1991). Melihat kecenderungannya sekarang, akuntansi konvensional lebih dekat pada kontribusi negatif. Namun, sumber utama permasalahan ini menurut Maunder dan Burrit (1991) berasal dari faktor sosiokultural termasuk antroposentrisma, egoisma dan ideologi yang mendorong perilaku yang menginginkan pertumbuhan ekonomi, efisiensi dan kepemilikan pribadi. Akuntabilitas lingkungan menjadi tanggung jawab semua pemangku kepentingan, eksekutif bisnis, pemerintah, masyarakat, profesi akuntansi termasuk mahasiswa akuntansi.

\subsubsection{Kinerja Lingkungan}

Menurut Suratno, dkk (2006), kinerja lingkungan perusahaan adalah kinerja perusahaan dalam menciptakan lingkungan yang baik (green). Penilaian kinerja lingkungan diukur dengan penilaian peringkat PROPER yang dilakukan oleh Kementerian Lingkungan Hidup. PROPER dilakukan dengan sistem pemeringkatan dengan pemberian warna sebagai penandanya. Terdapat lima peringkat dalam PROPER yaitu Emas, Hijau, Biru, Merah dan Hitam. Kinerja penataan yang dinilai dalam PROPER mencakup yaitu pada penataan terhadap pengendalian pencemaran air, udara, pengelolaan limbah B3, dan penerapan AMDAL (Analisis Mengenai Dampak Lingkungan). Sedangkan penilaian untuk aspek upaya lebih dari taat, yaitu meliputi penerapan sistem manajemen lingkungan, pemanfaatan limbah dan konservasi sumber daya, dan pelaksanaan kegiatan pengembangan masyarakat (community development).

\section{Tabel 2.2 Kriteria Peringkat PROPER}

\section{PERINGKAT WARNA}

\begin{tabular}{|c|c|}
\hline EMAS & $\begin{array}{l}\text { Untuk usaha dan atau kegiatan yang telah secara konsisten } \\
\text { menunjukkan keunggulan lingkungan (environmental } \\
\text { excellency) dalam proses produksi dan/atau jasa, } \\
\text { melaksanakan bisnis yang beretika dan bertanggung jawab } \\
\text { terhadap masyarakat. }\end{array}$ \\
\hline HIJAU & $\begin{array}{l}\text { Untuk usaha dan atau kegiatan yang telah melakukan } \\
\text { pengelolaan lingkungan lebih dari yang dipersyaratkan } \\
\text { dalam peraturan (beyond compliance) melalui pelaksanaan } \\
\text { sistem pengelolaan lingkungan, pemanfaatan sumber daya } \\
\text { secara efisien melalui upaya 4R (Reduce, Reuse, Recycle } \\
\text { dan Recovery), dan melakukan upaya tanggung jawab } \\
\text { sosial (CSR/Comdev) dengan baik. }\end{array}$ \\
\hline BIRU & $\begin{array}{l}\text { Untuk usaha dan atau kegiatan yang telah melakukan } \\
\text { upaya pengelolaan lingkungan yang dipersyaratkan sesuai } \\
\text { dengan ketentuan dan/atau peraturan perundang-undangan } \\
\text { yang berlaku. }\end{array}$ \\
\hline MERAH & $\begin{array}{l}\text { Upaya pengelolaan lingkungan yang dilakukan belum } \\
\text { sesuai dengan persyaratan sebagaimana diatur dalam }\end{array}$ \\
\hline
\end{tabular}


peraturan perundang-undangan dan dalam tahapan melaksanakan sanksi administrasi.

Untuk usaha dan atau kegiatan yang sengaja melakukan perbuatan atau melakukan kelalaian yang mengakibatkan

HITAM pencemaran dan/atau kerusakan lingkungan serta pelanggaran terhadap peraturan perundang-undangan yang berlaku atau tidak melaksanakan sanksi administrasi.

Sumber: Laporan Hasil Penilaian PROPER 2014 http:// proper.menlh.go.id/.

\subsubsection{Kinerja Komite Audit}

Komite Audit adalah suatu komite yang beranggotakan satu atau lebih anggota dewan komisaris dan dapat meminta kalangan luar dengan berbagai keahlian, pengalaman, dan kualitas lain yang dibutuhkan untuk mencapai tujuan komite audit, ini merupakan definisi menurut Komite Nasional Kebijakan Corporate Governance. Sedangkan menurut peraturan Otoritas Jasa Keuangan nomor 55 /POJK.04/2015 tentang Pembentukan dan Pedoman Pelaksanaan Kerja Komite Audit, diterangkan bahwa komite audit adalah komite yang dibentuk oleh dan bertanggung jawab kepada Dewan Komisaris dalam membantu melaksanakan tugas dan fungsi Dewan Komisaris.

\subsubsection{Kinerja Ekonomi Perusahaan}

Kinerja ekonomi perusahaan merupakan ukuran tertentu yang dilakukan untuk mengukur keberhasilan suatu entitas atau perusahaan dalam menghasilkan laba. Pengukuran kinerja dapat dilihat melalui laporan keuangan yang dikeluarkan perusahaan dalam periode tertentu. Serta kinerja ekonomi perusahaan juga bisa diukur melalui kinerja pasar dan kinerja fundamental perusahan. Menurut AlTuwaijri, et al. (2004), penelitian-penelitian sebelumnya menggunakan ukuran accounting-based dan market-based untuk mempresentasikan kinerja ekonomi. Pada penelitiannya, digunakan ukuran marketbased untuk mempresentasikan kinerja ekonomi yaitu dengan cara menggunakan industry-adjusted annual return yang didasarkan pada perhitungan selisih antara annual stock return dengan median dari kumpulan data annual stock return yang dianggap mampu mempresentasikan kinerja ekonomi secara lebih objektif dan komprehensif.

Keterangan:

$$
\frac{\left(P_{1}-P_{o}\right)+D i v}{P_{o}}-M e_{R I}
$$

$\mathrm{P}_{1} \quad$ : harga saham akhir tahun

$\mathrm{P}_{\mathrm{o}} \quad$ : harga saham awal tahun

Div : pembagian dividen

$\mathrm{Me}_{\mathrm{RI}} \quad$ : median return industry

\subsection{Hipotesis Penelitian}

\subsubsection{Pengaruh Kinerja Lingkungan Terhadap Kinerja Ekonomi Perusahaan}

Pada teori legitimasi disebutkan bahwa legitimasi adalah faktor yang strategis untuk membangun strategi perusahaan terutama untuk memposisikan perusahaan dengan lingkungan sosial (masyarakat). Perusahaan mencoba merespon masyarakat dengan memberikan kinerja lingkungannya. Dengan kinerja lingkungan yang baik, perusahaan secara tidak langsung menjaga kelangsungan di masa mendatang. Hal tersebut bisa dikatakan sebagai salah satu pencegahan untuk mengurangi biaya lingkungan di masa mendatang yang nantinya dapat berdampak positif pada kinerja ekonomi perusahaan.

Penelitian mengenai hubungan antara pengungkapan lingkungan dengan kinerja ekonomi cukup banyak dilakukan. Beberapa peneliti umumnya menggunakan variabel kinerja keuangan atau pasar modal sebagai prediktor bagi kinerja lingkungan itu sendiri (Berthelot, et al, 2003). Porter and Van Der Linde (1995) mengatakan bahwa perubahan kinerja lingkungan sebuah perusahaan dapat membawa ke kinerja ekonomi perusahaan yang lebih baik. Begitu juga Al-Tuwaijri, et al. (2004) yang menemukan hubungan positif signifikan antara kinerja ekonomi dengan kinerja lingkungan. Berdasarkan uraian di atas, maka hipotesis yang dirumuskan adalah: 
H1: Kinerja lingkungan berpengaruh terhadap kinerja ekonomi perusahaan.

\subsubsection{Pengaruh Kinerja Komite Audit terhadap Kinerja Ekonomi Perusahaan}

Komite audit bertanggung jawab untuk mengawasi laporan keuangan, mengawasi audit eksternal dan mengamati sistem pengendalian internal. Komite audit dapat mengurangi sifat oppotunistik manajemen yang melakukan manajemen laba dengan cara mengawasi laporan keuangan dan melakukan pengawasan pada audit eksternal. Integritas dan kredibilitas komite audit dalam pelaporan keuangan yaitu dengan melakukan pengawasan dalam proses pelaporan keuangan.

Beberapa penelitian menunjukkan hubungan positif antara kualitas Corporate Governance dengan kehandalan laporan keuangan. Perusahaan tanpa komite audit lebih mungkin terdapat kecurangan laporan keuangan (Dechow et al., 1996) dan komite audit yang berkualitas mampu membatasi dilakukannya manajemen laba dalam perusahaan (Anderson, 2003). Berdasarkan uraian tersebut, maka hipotesis yang dirumuskan adalah:

H2: Kinerja komite audit berpengaruh terhadap kinerja ekonomi perusahaan.

\subsection{Kerangka Konseptual}

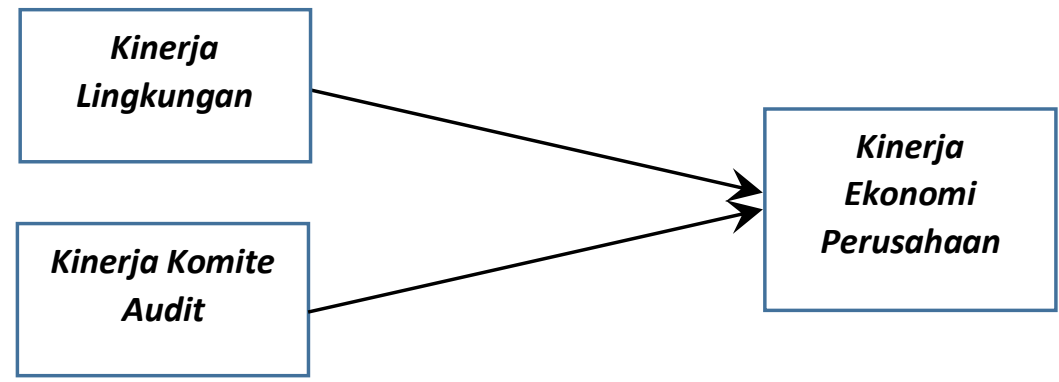

Gambar 2.1

Kerangka Konseptual

\section{Metode Penelitian}

\subsection{Pendekatan Penelitian}

Penelitian ini menggunakan pendekatan kuantitatif. Berdasarkan pendapat dari Indiantoro dan Supomo (1999:12), pendekatan kuantitatif menekankan pada pengujian teori-teori melalui pengukuran variabelvariabel penelitian dengan angka dan melakukan analisis data dengan prosedur statistik. Sehingga, dapat didefinisikan bahwa suatu proses yang menggunakan data berupa angka untuk menemukan pengetahuan sebagai alat menganalisis keterangan mengenai apa yang ingin diketahui merupakan pengertian pendekatan kuantitatif.

\subsection{Populasi dan Sampel}

Kumpulan dari seluruh pengukuran, baik objek atau pun individu yang sedang dikaji adalah definisi dari populasi menurut Harinaldi (2005:2). Dalam penelitian pengambilan sampel dilakukan dengan metode purposive sampling. Metode purposive sampling dipilih dengan tujuan untuk mendapatkan representative sample yang sesuai dengan kriteria yang ditentukan.

\subsection{Jenis dan Sumber Data}

Dalam penelitian ini, data sekunder diperoleh dari laporan PROPER yang sudah diterbitkan oleh Kementerian Lingkungan Hidup (KLH) guna mengetahui peringkat perusahaan, laporan keuangan 
perusahaan yang terdapat pada laman http://www.idx.co.id dan pada website perusahaan yang diteliti untuk mengetahui publikasi laporan tahunan perusahaan tersebut.

\subsection{Teknik Pengambilan Data}

Untuk memperoleh data sekunder yang berupa laporan keuangan tahunan dari berbagai macam perusahaan manufaktur yang terdaftar di BEI, peneliti menggunakan teknik dokumentasi. Definisi atau pengertian teknik dokumentasi yaitu mengumpulkan data sekunder dari berbagi sumber, baik secara pribadi maupun kelembagaan, sesuai dengan teknik yang diambil dalam karya Sanusi (2011:114). Dengan menggunakan instrumen ini, peneliti menganalisis dokumen-dokumen pendukung penelitian kemudian mengolah data tersebut sesuai dengan teori yang telah disusun.

\subsection{Definisi Operasional Variabel dan Pengukuran Variabel}

Variabel-variabel yang terdapat dalam penelitian ini adalah sebagai berikut:

\subsubsection{Variabel Dependen}

Kinerja ekonomi dalam penelitian ini didefinisikan sebagai kinerja perusahaan secara relatif dalam suatu industri sejenis yang ditandai dengan return tahunan perusahaan tersebut. Menurut Al-Tuwaijri, et al (2004), kinerja ekonomi dinyatakan dalam skala

hitung:

\section{Keterangan:}

$$
\frac{\left(P_{1}-P_{o}\right)+D i v}{P_{o}}-M e_{R I}
$$

\subsubsection{Variabel Independen}

\subsubsection{Kinerja Lingkungan $\left(X_{1}\right)$}

Pengukuran kinerja lingkungan dilakukan dengan melihat prestasi perusahaan yang mengikuti program PROPER. Sistem peringkat kinerja PROPER mencakup pemeringkatan perusahaan dalam lima warna yang akan diberi skor secara berturut-turut dengan nilai tertinggi 5 (lima) untuk warna emas, sedangkan nilai 4 (empat) untuk warna hijau, kemudian nilai 3 (tiga) untuk warna biru, lalu nilai 2 (dua) untuk warna merah dan terakhir, nilai terendah 1 (satu) untuk warna hitam.

\subsubsection{Kinerja Komite Audit $\left(X_{2}\right)$}

Sebagai indikator untuk kinerja komite audit pada penelitian ini, diambil tiga kriteria komite audit yaitu yang pertama, rapat komite audit, kemudian kedua yaitu laporan komite audit, serta yang tarakhir adalah piagam audit. Bagi objek yang memiliki ketiga kriteria tersebut akan diberi nilai 3 (tiga), jika hanya dua diantaranya akan mendapat nilai 2 (dua), dan kemudian jika hanya satu akan mendapat nilai 1 (satu).

\subsection{Teknik Analisa Data}

\subsubsection{Statistik Deskriptif}

Statistik deskriptif merupakan bagian dari statistik yang menitik-beratkan pada pengumpulan, penyajian, pengolahan, serta peringkasan data; tapi tidak berlanjut pada penarikan kesimpulan. Nantinya, penyusunan data dalam daftar atau tabel dan visualisasi, dalam bentuk diagram atau grafik 
dilakukan melalui statistik deskriptif ini. Selain itu, pengolahan data serta interpretasi terhadapnya mungkin saja dilakukan, dengan catatan bahwa kegiatan itu tidak sampai pada penarikan kesimpulan yang berlaku umum berikut dikutip dari karya Santoso (2001:150).

\subsubsection{Uji Asumsi Klasik}

\subsubsection{Uji Normalitas}

Berdasarkan hail penelitian yang dilakukan oleh Ghozali (2009: 160), tujuan diadakannya uji normalitas data adalah untuk menguji apakah dalam regresi, variabel pengganggu atau residu memiliki distribusi normal atau tidak. Pengujian normalitas dapat dilakukan melalui metode grafik dan uji KolmogorovSmirnov (Gozali, 2009: 32)

\subsubsection{Uji Multikolinieritas}

Uji multikolinearitas bertujuan menguji apakah dalam model regresi ditemukan adanya korelasi antarvariabel bebas (independen) atau tidak. Karena menurut pendapat Ghozali, model regresi yang baik harus terbebas dari korelasi antar variabel bebas (2009:105).

\subsubsection{Uji Autokorelasi}

Suatu uji yang bertujuan untuk mengetahui apakah data periode sebelumnya mempengaruhi data yang ada pada periode sekarang, merupakan definisi dari pengertian uji autokorelasi. Untuk mengetahui apakah data yang digunakan dalam model regresi tersebut terdapat autokorelasi atau tidak, dapat diketahui melalui Uji Durbin-Watson (DW), berdasarkan dari penelitian dari Gozali (2009: 110).

\subsubsection{Uji Heteroskedastisitas}

Pengujian heteroskedastisitas dilakukan dengan menggunakan Uji Glejser yang dilakukan dengan meregresikan variabel-variabel bebas terhadap nilai absolut residualnya. Sesuai dengan pendapat Ghozali (2009:142), dapat diketahui jika semua variabel bebas memiliki probabilitas signifikansi di atas kepercayaan 5\% (0,05), maka dapat disimpulkan tidak ada heterokedastisitas. Sebaliknya, jika ada variabel bebas yang memiliki probabilitas signifikansi di bawah 5\% $(0,05)$ maka terdapat heterokedastisitas.

\subsubsection{Analisis Linier Berganda}

Model analisis regresi berganda yaitu adalah metode analisis yang digunakan dalam penelitian ini. Hal itu berarti bahwa penelitian ini akan menerangkan pengaruh langsung dan tidak langsung variabel bebas (dependen), terhadap variabel terikat (independen). Oleh karena itu, model regresi yang digunakan dalam penelitian ini adalah:

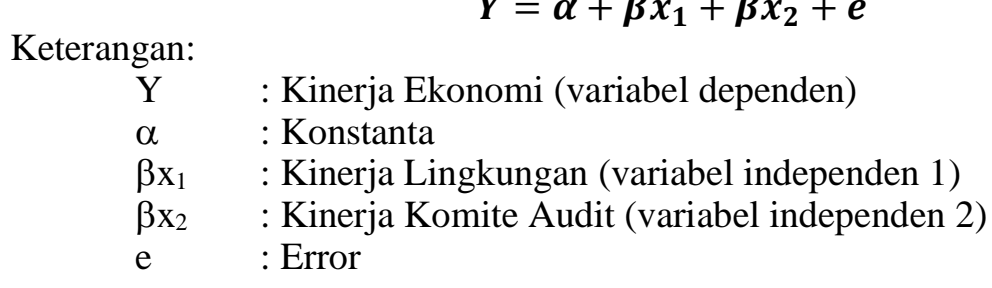

\subsubsection{Uji Hipotesis}

\subsubsection{Uji Statistikt}


Untuk membuktikan pengaruh yang signifikan antara variabel independen terhadap variabel dependen, dapat digunakan dengan menerapkan uji $\boldsymbol{t}$, yaitu dimana apabila nilai $\boldsymbol{t}$ hitung lebih besar daripada $\boldsymbol{t}$ tabel, berarti menunjukkan diterimanya hipotesis yang diajukan. Uji ini dilakukan dengan syarat yaitu:

a. Bila $\boldsymbol{t}$ hitung $>\boldsymbol{t}$ tabel maka $\boldsymbol{H}_{\boldsymbol{0}}$ diterima dan ditolak $\boldsymbol{H}_{\boldsymbol{a}}$ artinya bahwa secara bersama - sama variabel independen tidak berpengaruh terhadap variabel dependen.

b. Bila $\boldsymbol{t}$ hitung $<\boldsymbol{t}$ tabel maka $\boldsymbol{H}_{\boldsymbol{0}}$ ditolak dan menerima $\boldsymbol{H}_{\boldsymbol{a}}$ artinya bahwa secara bersama - sama variabel independen berpengaruh terhadap variabel dependen.

\section{Hasil Penelitian Dan Interpretasi Data}

\subsection{Deskripsi Data Penelitian}

Objek penelitian ini adalah perusahaan yang terdaftar di Bursa Efek Indonesia (BEI). Selain itu, perusahaan yang diteliti juga harus mengikuti Program Penilaian Peringkat Kinerja Perusahaan (PROPER). Pengambilan sampel penelitian dilakukan dengan metode purposive sampling dari perusahaan-perusahaan manufaktur yang secara berturut-turut terdafatar di BEI selama periode 20142016. Selain itu juga, perusahaan harus mengikuti PROPER pada tahun berjalan dan juga menerbitkan laporan tahunan perusahaan. Sampel perusahaaan adalah 22 perusahaan.

\subsection{Analisis Data}

\subsubsection{Statistik Deskriptif}

Analisis pertama dalam penelitian ini adalah statistik deskriptif. Hasil analisis statistik dapat dilihat pada tabel 4.6 berikut.

Tabel 4.6

Analisis Statistik Deskriptif

\begin{tabular}{|l|c|c|c|c|c|}
\hline & $\mathrm{N}$ & Minimum & Maximum & Mean & $\begin{array}{c}\text { Std. } \\
\text { Deviation }\end{array}$ \\
\hline $\begin{array}{l}\text { Kinerja Ekonomi } \\
\text { Perusahaan }\end{array}$ & 66 & $-0,475$ & 8,714 & 0,30499 & 1,156047 \\
\hline Kinerja Lingkungan & 66 & 2,00 & 5,00 & 3,0909 & 0,41979 \\
\hline Kinerja Komite Audit & 66 & 0,00 & 3,00 & 2,5909 & 0,58117 \\
\hline Valid N (listwise) & 66 & & & & \\
\hline
\end{tabular}

Sumber: Data sekunder yang diolah (Lampiran 7.1)

Hasil deskriptif kinerja lingkungan menunjukkan rata-rata sebesar 3,0909. Nilai minimum 2,00 dan nilai maksimum kinerja lingkungan sebesar 5,00 dengan standard deviasinya 0,41979. Perusahaan dalam sampel penelitian rata-rata memiliki peringkat kinerja lingkungan (Nilai PROPER) biru. Sedangkan yang paling rendah memiliki kinerja lingkungan merah, namun juga ada satu perusahaan yang memiliki peringkat emas. Kinerja ekonomi perusahaan dihitung menggunakan skala hitung yang menunjukkan nilai rata-rata 0,30499 dengan nilai minimum -0,475; nilai maksimum 8,714 sedangkan nilai standard deviasi 1,156047 .

\subsubsection{Uji Asumsi Klasik}

\subsubsection{Uji Normalitas}

Uji normalitas dalam sebuah penelitian digunakan untuk mengetahui apakah data yang diolah dalam penelitian terdistribusi normal atau tidak. hasil uji normalitas dapat dijelaskan bahwa variabel-variabel dalam penelitian ini (kinerja lingkungan dan kinerja komite audit) mempunyai tingkat signifikansi lebih dari 0,05. Hal tersebut dapat dilihat dari nilai Asyimp. Sig (2-tailed) sebesar 0,087. Sehingga, data dalam penelitian ini dapat dikatakan terdisitribusi normal. 


\subsubsection{Uji Multikolinieritas}

Uji multikolinieritas digunakan untuk mengetahui ada tidaknya hubungan antara variabel dependen dengan variabel independen dalam sebuah penelitian. Hasil pengolahan data menunjukkan kedua variabel bebas yang diteliti nilai tolerance dan VIF sebesar 0,941 dan 1,063. Sehingga model regresi pada penelitan ini tidak mengalami gejala multikolineratias.

\subsubsection{Uji Heteroskedastisitas}

Uji heteroskedastisitas berfungsi untuk menguji ketidaksamaan varian dari residual pengamatan satu kepengamatan lainnya. Hasil pengolahan data dapat disimpulkan bahwa nilai signifikansi kedua variabel independen (kinerja lingkungan dan kinerja komite audit) sebesar 0,812 dan 0,418 yang nilainya lebih dari 0,05. Dengan demikian, dapat dikatakan bahwa model regeresi ini bebas dari heteroskedastisitas.

\subsubsection{Uji Autokorelasi}

Ada tidaknya autokorelasi dilakukan pengujian Durbin Watson. Hasil uji dw (Durbin Watson) adalah menunjukkan hasil uji dw, diperoleh 1,6406 < 2,171 < 2,3594. Dapat disimpulkan bahwa dalam penelitian ini tidak terjadi atukorelasi positif dan negatif, sehingga dengan kata lain model regresi bebas dari autokorelasi.

\subsubsection{Analisis Regresi Linier Berganda}

Analisis regresi linier berganda berfungsi untuk meneliti hubungan antar variabel. Dalam penelitian ini diketahui bahwa variabel dependennya adalah kinerja ekonomi dan variabel independennya adalah kinerja lingkungan dan kinerja komite audit. Sehingga, dapat diperoleh persamaan regresi linier berganda sebagai berikut:

$$
\mathrm{Y}=0,719-0,129 \mathrm{X}_{1}-0,101 \mathrm{X}_{2}+\mathrm{e}
$$

\subsubsection{Uji Hipotesis}

\subsubsection{Signifikansi Simultan (Uji F)}

Pengujian ini dilakukan untuk menguji ada tidaknya pengaruh secara bersama-sama dari variabel independen (kinerja lingkungan dan kinerja komite audit) terhadap variabel dependennya (kinerja ekonomi perusahaan) dengan nilai $\boldsymbol{\alpha}=0,05$. Hasil uji $\mathbf{f}$ bahwa nilai $\mathbf{F}$ hitung sebesar 4,657 dengan nilai siginfikansi sebesar 0,014. Karena nilai toleransi 0,05, hasil 0,014 $<0,05$ sehingga $\mathbf{H}_{\mathbf{0}}$ ditolak dan $\mathbf{H a}$ diterima. Hal ini berarti variabel kinerja lingkungan dan kinerja komite audit secara simultan berpengaruh signifikan terhadap kinerja ekonomi perusahaan, sehingga besar kecilnya variabel independen tersebut mempengaruhi kinerja ekonomi perusahaan.

\subsubsection{Uji Signifikansi Parameter Individual (Uji Statistik t)}

Pengujian ini dilakukan untuk mengukur seberapa besar pengaruh masing-masing variabel independen (kinerja lingkungan dan kinerja komite audit) secara parsial terhadap kinerja ekonomi perusahaan dengan menggunakan uji hipotesis dengan $\boldsymbol{\alpha}=0,05$.

\section{Tabel 4.13}

Hasil Uji T test

\begin{tabular}{|l|r|l|l|}
\hline \multicolumn{1}{|c|}{ Model } & T & Sig. & Kesimpulan \\
\hline (Constant) & 3,227 & 0,002 & \\
\hline KL & $-2,384$ & 0,021 & Signifikan \\
\hline KA & $-2,429$ & 0,019 & Signifikan \\
\hline
\end{tabular}

Sumber: data sekunder yang diolah (Lampiran 7.4.2) 


\subsubsection{Koefisian Determinasi $\left(R^{2}\right)$}

Koefisien determinasi $\left(\mathrm{R}^{2}\right)$ atau disebut juga ketetapan perkiraan model (Goodness of Fit) digunakan untuk mengukur apakah variabel independen atau kinerja lingkungan dan kinerja komite audit mampu menerangkan variabel dependen (kinerja ekonomi perusahaan). Berikut adalah hasil perhitungan Adjusted R Square.

Tabel 4.14

Hasil Pengujian Koefisien Determinasi

\begin{tabular}{|l|l|r|r|c|c|}
\hline Model & R & R Square & $\begin{array}{c}\text { Adjusted R } \\
\text { Square }\end{array}$ & $\begin{array}{l}\text { Std. Error of } \\
\text { the Estimate }\end{array}$ & $\begin{array}{l}\text { Durbin- } \\
\text { Watson }\end{array}$ \\
\hline 1 & $0,390^{\mathrm{a}}$ & 0,152 & 0,119 & 0,177060 & 2,171 \\
\hline
\end{tabular}

Sumber: data sekunder yang diolah (Lampiran 7.4.3)

Hasil pengujian $\mathrm{R}^{2}$ menunjukkan nilai Adjusted $\boldsymbol{R}$ Square adalah 0,119 atau 11,9\%. Hal tersebut menunjukkan pengaruh variabel independen (kinerja lingkungan dan kinerja komite audit) terhadap variabel dependen (kinerja ekonomi perusahaan) hanya sebesar 11,9\%. Dengan kata lain, variabel independen berpengaruh sangat kecil dan ada variabel di luar faktor sebesar $88,1 \%$ yang mungkin berpengaruh.

\subsection{Interpretasi Hasil}

Setelah dilakukan pengujian sebagaimana telah diuraikan diatas, diperoleh interpreatsi hasil sebagai berikut:

\subsubsection{Pengaruh Kinerja Lingkungan Terhadap Kinerja Ekonomi Perusahaan}

Suratno, dkk (2006) menerangkan, "kinerja lingkunga perusaan adalah kinerja perusahaan dalam menciptakan lingkungan yang baik (green)". Kinerja lingkungan diukur menggunakan PROPER oleh Kementrian Lingkungan Hidup. Penilaian ini bertujuan untuk meningkatkan kinerja perusahaan dalam pelestarian di bidang lingkungan. Pada tabel 4.10 di uraian sebelumnya, menunjukkan pengujian kinerja lingkungan sebesar -2,384 (bertanda negatif) dengan koefisiensi sebesar 0,021<0,05. Hal tersebut berarti kinerja lingkungan berpengaruh signifikan terhadap kinerja ekonomi perusahaan. Penilaian PROPER oleh kementerian lingkungan hidup secara tidak langsung ikut dalam mendorong kinerja ekonomi perusahaan.

Perusahaan yang mengikuti PROPER, berarti meningkatkan kepercayaan pemangku kepentingan dalam mengambil sikap investasi sehingga mendorong kinerja ekonomi yang baik bagi perusahaan. Penelitian ini sejalan dengan yang telah diteliti oleh Freedman (1962) yang menyatakan kinerja lingkungan mempunyai korelasi negatif dengan kinerja ekonomi. Serta mendukung penelitian Berthelot, et al, (2003), Porter and Van Der Linde (1995) dan juga penelitian Al- Tuwaijri, et al. (2004) yang menjelaskan bahwa perubahan kinerja lingkungan sebuah perusahaan dapat membuat kinerja ekonomi perusahaan baik.

\subsubsection{Pengaruh Kinerja Komite Audit terhadap Kinerja Ekonomi Perusahaan}

Di dalam Kep. 29/PM/2004 disebutkan bahwa, "komite audit adalah komite yang dibentuk oleh dewan komisaris untuk membantu melaksanakan tugas dan fungsinya". Komite audit berkualitas adalah salah satu komponen dalam tata kelola perusahaan yang baik. Tugas dan tanggung jawab komite audit sendiri adalah untuk memastikan prinsip-prinsip tata kelola perusahaan (transparasi) telah sesuai diterapkan secara konsisten dan memadahi atau tidak. Penerapan prinsip tersebut berkaitan dengan integritas kinerja ekonomi perusahaan. Hasil pengujian yang telah diuraikan sebelumnya pada tabel 4.10, menunjukkan kinerja audit sebesar $-2,429$ (negatif) dengan nilai signifikansi $0,019<0,05$. Hasil pengujian tersebut menunjukkan bahwa kinerja komite audit berpengaruh signifikan terhadap kinerja ekonomi perusahaan. Dengan kata lain, kuantitas jumlah rapat komite audit, ada tidaknya laporan audit dan piagam audit dapat mempengaruhi kinerja ekonomi. Sejalan dengan penelitian Ningtyas, et al (2014) yang menyatakan hubungan korelasi negatif antara komite audit dengan kinerja ekonomi.

Adanya komite audit yang berkompeten yang bertanggung jawab untuk mengawasi laporan keuangan, mengawasi audit eksternal dan mengamati sistem pengendalian internal dalam perusahaan 
mampu membuat para pemangku kepentingan dalam mempertimbangkan investasinya. Sehingga hal tersebut mampu berdampak pada kinerja ekonomi perusahaan yang lebih baik lagi. Penelitian ini sejalan dengan penelitian Siallagan dan Machfoedz (2006) yang menunjukkan mekanisme corporate governance melalui komite audit berpengaruh terhadap nilai perusahaan. Hasil penelitian ini juga bersesuaian dengan penelitian Anderson, et al (2003) yang menyatakan pendapatan menjadi lebih besar dan informati dnegan komposisi dewan komite audit yang lengkap.

\section{Kesimpulan dan Saran}

\subsection{Simpulan}

Setelah dilakukan pengamatan dan pengujian terhadap penelitian yang berjudul "Pengaruh Kinerja Lingkungan Dan Kinerja Komite Audit Terhadap Kinerja Ekonomi Perusahaan" ini, dapat disimpulkan sebagai berikut:

a. Kinerja lingkungan mampu berpengaruh secara signifikan terhadap kinerja ekonomi. Penilaian PROPER oleh kementerian lingkungan hidup secara tidak langsung ikut dalam mendorong kinerja ekonomi perusahaan. Dengan adanya perusahaan yang mengikuti PROPER, dapat meningkatkan kepercayaan pemangku kepentingan dalam mengambil sikap investasi, sehingga dapat mendorong kinerja ekonomi yang baik bagi perusahaan. Turut sertanya perusahaan berkontribusi dalam pelestarian lingkungan berdampak juga pada kinerja ekonominya. Penelitian ini sejalan dengan Freedman (1962), Berthelot, et al, (2003), Porter and van der Linde (1995) dan juga Al- Tuwaijri, et al. (2004) yang menjelaskan bahwa perubahan kinerja lingkungan sebuah perusahaan berpengaruh terhadap kinerja ekonomi perusahaan.

b. Kinerja komite audit berpengaruh secara signifikan terhadap kinerja ekonomi perusahaan. Hal tersebut membuktikan bahwa rapat komite audit, piagam audit dan laporan audit dapat mempengaruhi kinerja ekonomi perusahaan. Hasil penelitin yang telah dilakukan ini sesuai dengan penelitian Ningtyas, et al (2014) yang menyatakan komite audit berpengaruh negatif terhadap kinerja ekonomi. Siallagan dan Machfoedz (2006) yang menyimpulkan ada pengaruh antara mekanisme GCG (komite audit) terhadap kinerja perusahaan. Selain itu, hasil penelitian ini bersesuaian dengan penelitian Anderson, et al (2003) yang menyatakan pendapatan menjadi lebih besar dan informati dnegan komposisi dewan komite audit yang lengkap.

\subsection{Keterbatasan}

Keterbatasan dalam penelitian ini yaitu pada sampel penelitian yang terbatas pada perusahaan manufaktur. Sehingga, jumlah sampel perusahaan dirasa kurang dalam sebuah penelitian. Dan juga dalam penggunaan variabel. Variabel independen yang digunakan hanya terbatas pada dua variabel saja (kinerja lingkungan dan kinerja komite audit). Sehingga, nilai untuk adjusted $\boldsymbol{R}^{2}$ sebesar $11,9 \%$ yang mana kurang bisa mewakili pengaruh variabel independen penelitian terhadap variabel dependennya.

\subsection{Rekomendasi}

Penulis menyadari adanya keterbatasan dalam penelitian ini, penulis mengharapkan adanya pengembangan pada penelitian selanjutnya. Penelitian selanjutnya diharapkan untuk menambah variabel independen lainnya yang mungkin berpengaruh terhadap kinerja ekonomi perusahaan. Seperti kebijakan Corporate Social Responsibility (CSR) yang dikeluarkan perusahaan. Sehingga selain lingkungan hidup lingkungan sosial juga bisa menjadi salah satu indikator dalam mengukur kinerja perusahaan.

Pada penelitian ini sampel yang digunakan hanya terbatas pada perusahaan manufaktur. Diharapkan pada penelitian selanjutnya penambahan sektor perusahaan tambang sebagai sampel penelitian. Perusahaan tambang sendiri merupakan perusahaan yang mengeksploitasi lingkungan hidup, sehingga perlu dilakukan penelitian yang lebih mendalam tentang kinerja lingkungan perusahaan tambang terhadap kinerja ekonominya.

\section{Daftar Pustaka}


Al-Tuwaijri S.A., Christensen T.E. dan Hughes K.E. 2004. The Relations Among Environmental disclosure, Environmental performance and Economic performance. Accounting Organizations and Society. Vol. 29. Hal. 447-471.

Almilia, L. S dan Wijiyanto,D. 2007. Pengaruh environmental performance dan disclosure terhadap economic performance. Proocedings The 1st Accounting Conference Depok: $1-23$.

Anderson, K.L., Deli, D.N., dan Gillan, S.T. 2003. Board of Directors, Audit Committees, and the Information Content of Earnings. Working Papers.

Bertehelot, Sylvie; Denis Cormier; Michel Magnan. 2003. Environemntal Disclosure Research: Review and Synthesis. Journal of Accounting Review. 22. 1-44.

Dechow P., Sloan R., Sweeney A.P. 1996. Causes and Consequences of Earnings Manipulation. Contemporary accounting research, volume 13, pp. 1-36.

Departemen Pendidikan dan Kebudayaan. 1997. Kamus Besar Bahasa Indonesia. Jakarta : Balai Pustaka.

Forum for Corporate governance in Indonesia (FCGI). 2002. The Essence of Good Corporate governance: Konsep dan Implementasi Perusahaan Publik dan Korporasi Indonesia. Jakarta: Yayasan Pendidikan Pasar Modal Indonesia dan Sinergy Communication. Jakarta.

Friedman, M. (1962). Capitalism and freedom. Chicago: The University of Chicago Press, Phoenix Books.

Gray R., Javad M., David M.P., \& Donald S. 2001. Social And Enviromentalisep:Disclosure And corporate Characteristics: A Research Note and Extension. Journal of Business Finance and Accounting, 44 (5); 327-356.

Ghozali, Achmad dan Chariri. 2007. Teori Akuntansi. Yogyakarta: Penerbit Andi,

Ghozali, Imam. 2009. Aplikasi Analisis Multivariate Dengan Program SPSS Edisi Keempat. Semarang : Penerbit Universitas Diponegoro.

Harinaldi, M.Eng. 2005. Prinsip-Prinsip Statistik Untuk Teknik Dan Sains. Jakarta: Penerbit Erlangga. Indriantoro, Nurdan dan Supomo, Bambang. 1999. Metodologi Penelitian Bisnis Untuk Akuntansi \& Manajemen. Yogyakarta : Penerbit BPFE.

Jogiyanto.2000. Sistem Informasi Berbasis Komputer Konsep Dasar dan Komponen Edisi Kedua. Yogyakarta: BPFE.

Kementerian Lingkungan Hidup. 2014. Proper. Di- unduh tanggal 10 April 2017, http:// proper.menlh.go.id/.

Lindrianasari. 2007. Hubungan Antara Kinerja Lingkungan dan Kualitas Pengungkapan Lingkungan dengan Kinerja Ekonomi Perusahaan di Indonesia. Jurnal Akuntansi \& Auditing Indonesia, 11 (2).

Ningtyas, Suhadak \& Nuzula. 2014. Pengaruh Good Corporate Governance Terhadap Nilai Perusahaan (Studi pada Perusahaan yang terdaftar di Jakarta Islamic Index tahun 2010-2013). Jurnal Adminstrasi Bisnis (JAB) Vol. 17 No. 1.

Maunders, K., T, and R. L. Burritt: 1991. Accounting and Ecological Response Crisis. Accounting Auditing and Accountability Journal, 4: 9-24.

Melewar. T. C (Ed.). 2008. Facets of Corporate Identity, Communication, and Reputation. New York : Routledge. 
Mulyadi. 2001. Sistem Akuntansi Edisi Tiga. Jakarta : Salemba Empat.

O'Donovan, G. (2002). Environmental disclosures in the annual report: Extending the applicability and predictive power of legitimacy theory, Accounting Organizations and Society. Vol. 15 No.3, pp. 344-371.

Porter, M. dan van der Linde, C. 1995a. Green and Competitive: Ending the Stalemate. Harvard Business Review. Vol. 73(5). pp.120-134.

Rakhiemah A.N., \& Agustia D. 2009. Pengaruh Kinerja Lingkungan terhadap Corporate Social Responsibility (CSR) Disclosure dan Kinerja Finansial Perusahaan Manufaktur yang Terdaftar di Bursa efek Indonesia. Simposium Nasional Indonesia 12. Palembang.

Santoso. S. 2001. SPSS Statistik Parametrik. Jakarta: PT Elex Media Komputindo.

Sanusi, Anwar. 2011. Metode Penelitian Bisnis. Jakarta: Salemba Empat.

Sarumpaet, Susi. 2005. The Relationship Between Environmental Performance and financial performance of Indonesian companies. Jurnal Akuntansi dan Keuangan, Volume 7, Nomor 2. Universitas Kristen Petra.

Sekaran, U. 2006. Metodologi Penelitian Untuk Bisnis. Edisi 4. Jakarta: Salemba Empat.

Setyaningsih, Riska Dewi dan Asyik, Nur Fadjrin. 2016. Pengaruh Kinerja Lingkungan Terhadap Kinerja Keuangan dengan Corporate Social Responsibility Sebagai Pemoderasi. Jurnal Ilmu dan Riset Akuntansi : Volume 5.

Siallagan, Hamonangan dan Machfoedz, Mas'ud. 2006. Mekanisme Corporare Governance, Kualitas Laba dan Nilai Perusahaan. Simposium Nasional Akutansi 9 Padang.

Siregar, Ivana; Lindrianasari; Komarruddin. 2013. Hubungan Antara Kinerja Lingkungan dan Kinerja Komite Audit dengan Kualitas Pengungkapan Corporate Social Responsibility. Jurnal Akuntansi dan Keuangan. Vol 4 No 1 63-84

Sucipto. 2003. Penilaian Kinerja Keuangan. Medan: Universitas Sumatera Utara.

Suratno, Ignatius Bondan, Darsono, dan Mutmainah S. 2006. Pengaruh Environmental Performance terhadap Environmental Disclosure dan Economic Performance. Simposium Nasional Akuntansi 9 , Padang.

Watts, Ross L and Zimmerman, Jerold L. 1986. Positive Acconting Theory. Prentice-Hall Inc. 